\title{
FOOD STRATEGIES AND RESTITUTION OF URBAN AGRICULTURE ILLUSTRATED BY THE CASE OF SELECTED SOLUTIONS OF METROPOLITAN AREAS
}

\author{
Aleksandra PŁONKA ${ }^{1 *}$, Wojciech SROKA ${ }^{2}$ \\ ${ }^{1}$ University of Agriculture in Krakow, Faculty of Agriculture and Economics, Krakow; \\ aleksandra.plonka@urk.edu.pl, ORCID: 0000-0001-5319-592X \\ ${ }^{2}$ University of Agriculture in Krakow, Faculty of Agriculture and Economics, Krakow; \\ wojciech.sroka@urk.edu.pl, ORCID: 0000-0002-4255-3741 \\ * Correspondence author
}

Purpose: The purpose of the paper was to present and emphasise the importance of the concept of food strategies in creating sustainable development of metropolitan areas and restitution of agriculture. By reviewing Canadian and French solutions, among other things, an attempt was made to indicate the importance of urban agriculture in shaping sustainable development (SD) of metropolitan areas.

Design/methodology/approach: In order to illuminate the phenomenon of urban strategic planning in the restitution and development of urban agriculture, a descriptive case study was adopted as the methodology of qualitative research, where the empirical basis consisted mainly of urban plans of selected cities, study of the subject literature and analysis of selected legislative acts.

Findings: The presented models of coherence building at a local level show that only planning and new generation strategic plans of a metropolis that take into into account urban food systems are able to balance long-term development objectives and protect natural resources for future generations. Such a model is characterised by not only innovative methodology of planning, but also innovative operational instruments and new ways of implementation.

Practical implications: using accumulated knowledge and experience in managing sustainable development of cities.

Originality/value: presenting world standards in planning sustainable development of cities and emphasising the importance of urban food production and agriculture as a zone of a metropolis's natural balance.

Keywords: food strategies, metropolitan area, urban agriculture.

Category of the paper: case study. 


\section{Introduction}

At a time of urban civilisation struggling with negative effects of climate changes, an important question is how cities (in particular those densely populated) will ensure food security and sovereignty to their inhabitants, while increasing their self-sufficiency. Many metropolises around the world seek to become independent from food import from rural areas by locating agricultural production within their borders (Demailly, and Darly, 2017).

The rediscovery of gardens and food production in cities has revived a stream of research on urban and peri-urban agriculture (UPUA $\left.{ }^{1}\right)$ defined as "the growing of plants and the raising of animals within and around cities" (FAO, 2019). Urban agriculture has gained in importance in recent decades, starting to fulfil a more and more significant role in the creation of local, alternative food systems. It is becoming an important topic, especially in the context of the popularity of the idea of sustainable development. There is a clear agreement among urban decision makers and scholars in highly developed countries that urban agriculture could be a tenable way of enhancing urban sustainability (Sarker et al., 2019; Ayambire et al., 2019). UPUA is seen as having the potential to contribute to more sustainable and resilient cities (Ferreira et al., 2018). The literature also stresses that agriculture, through its economic, social and ecological functions, presents potentials for meeting some of the targets of the 11th Sustainable Development Goal (Azunre et al., 2019). Moreover, numerous authors pinpoint that urban agriculture has a wide array of functions, such as environmental, social, economic and even cultural (Specht, 2016).

Given the huge urban pressure and dynamic development of cities, scholars agree that urban and peri-urban agriculture can only be sustained if city authorities consciously integrate it into the urban spatial planning processes (Azunre et al., 2019). A number of policies, solutions and tools are currently employed to protect arable land against urban expansion and encourage people to carry out agricultural activity in cities, including coordination of food supply actions. Among them, of importance are zoning policy, agricultural buffers, 'Right to farm' ordinances, acquisition of farmland through trusts, taxation, and national legal regulations, etc. (Spataru et al., 2020).

The different tools for improving the functioning of agri-food systems designed to provide city inhabitants with food are used in different countries to varying extends and with varying results (Ayambire et al., 2019), constituting a wide range of solutions that can be implemented in other places. This study presents examples of solutions/practices that can facilitate the integration of urban agriculture with urban spatial planning. The paper concentrates on presenting solutions that include urban food systems within the sphere of urban planning, with a particular focus on the restitution of agriculture and farmland in selected cities of the United States, Canada and Europe.

\footnotetext{
${ }^{1}$ Urban and peri-urban agriculture - UPUA.
} 
The purpose of the paper was to present and emphasise the importance of the concept of food strategies in creating sustainable development of metropolitan areas and restitution of agriculture.

\section{Material and the research method}

The paper presents results of analyses reviewing selected solutions that included food strategy into urban strategic planning systems.

The use of the examples of world metropolises was intentional. A lot of attention was given in particular to French solutions. This is because urban strategic planning in France, its position and role, are regarded in Europe as a model - also with regard to the issue of farmland preservation (Perrin et al., 2020). France - through its experts and professionals in the field grouped e.g. in the Federation of Urban Planning Agencies, which is independent from municipal authorities - has made a significant contribution to the shaping of EU urban policy. Moreover, urban planning in France is constantly improved so that arrangements made at the EU level can be implemented both at the governmental and local levels (Geppert, 2015).

In order to illuminate the phenomenon of urban strategic planning in the restitution and development of urban agriculture, a descriptive case study was adopted as the methodology of qualitative research. The materials and key data ware derived from the literature on the subject, selected legislative acts and documents related to the field. A study visit to the Lyon Urban Planning Agency and urban documents received there also contributed to gaining a deeper understanding of the French planning system.

An in-depth insight into the issue was gained, and detailed analyses of urban documents were conducted with the help of an urban development expert operating in the Team Europe network established under the European Commission. Given the importance of the subject and its in-depth analysis, the results of the study were found satisfactory and worth presenting to a wider audience. The description of the presented solutions should give the reader an idea of what a plan of the conditions and directions of a land use in a city, municipality or region should be and how it should function.

\section{Food strategy as an official document}

As a rule, food-related matters have always been perceived as a problem of agriculture and rural areas. However, historically, urban development and food supply to cities have always been interdependent. For many years, various groups in many countries have demanded from 
municipal authorities to take an interest in the issues of agriculture, reflect on the functioning of the urban food system and place the food system within the sphere of urban planning. Demands were put forward by inhabitants, and pressure was put by planners and practitioners as well as academic circles. Yet, the problem of food for cities is still viewed in many countries worldwide in terms of supply and demand or free market.

Many cities, in particular large and densely populated ones, attach growing importance to coordination of food supply activities. The biggest metropolises of the United States, Canada or Europe give more consideration to improvement of agri-food systems designed to provide inhabitants with food. In order to efficiently manage both agricultural areas and food security of their inhabitants, metropolises such as London, New York, Vancouver or Toronto draw up documents, in addition to strategic urban spatial plans, to facilitate the implementation of food strategies. London City developed the Urban Agriculture Strategy and declares that it implements it through cooperation between the city and urban community (Urban..., 2018). Vancouver has its Local Food Action Plan (Local..., 2013). Montreal is implementing the provisions of the Metropolitan Management and Development Plan that includes the Agricultural Zone Development Plan (Rapport..., 2015). In Paris, there is the Directional Scheme of the Île-de-France Region (Schéma..., 1976, 1994) which places agriculture within the sphere of responsibility of urban policy due to its unprecedented function of balancing urban built-up areas. Meanwhile, in the Directional Scheme of the Rhône-Alpes Region and its capital Lyon agricultural areas were recognised as an economic area in its own right, which, additionally, due to its specificity, requires stability in terms of its borders, area and time (Lyon, 1991, 2010). Other cities draw up food strategies, among other things - if not for the metropolis as a whole, then for individual districts or agricultural zones.

According to Mansfield and Mendesa (2012), who conduct studies into municipal food strategies and integrated approaches to urban agriculture in the largest cities of Canada and the United States, the fundamental role of cities is to identify the weaknesses of the food system. The only response of local authorities is to re-focus on the integrating approach to urban agriculture and on combining numerous separate food problems into one system. The authors note lack of comprehensive urban food strategies that would address these problems in a coordinated manner. According to them, urban food strategy should be understood as a formal "official" plan or a roadmap that helps municipal authorities to place the full spectrum of food system issues within a "uniform political framework". The idea is to integrate the issues of food production (to which the term of urban and peri-urban agriculture corresponds in strict sense), processing, and distribution, food access and waste management (Mansfield, and Mendes, 2012). 


\section{Food strategies in selected metropolises and regions}

In North American cities, urban agriculture was already recognised in the early 1970s, but its planning did not develop on a wider scale until the late 1990s (Pothukuchi, and Kaufman, 2000). The issues of urban agriculture and food production in cities started to become a subject of more extensive research, but also cooperation between e.g. scholars and local authorities. In the USA and Canada, scholars (Mansfield, and Mendes, 2012; Bhatt, and Farah, 2016, among others) along with urban planners and representatives of local administration reviewed a dozen or so cities to find out how urban agriculture is addressed in spatial development plans. Also in Europe, already a decade ago, at the initiative of inter alia the Association of European Schools of Planning (AESOP ${ }^{2}$ ), academic urban planners and practitioners addressed the issue of territorial planning of sustainable food for cities (Vidal, and Fleury, 2009, among others). These studies present a wide range of the examples of solutions that were applied and successfully implemented in selected metropolises regarded as pioneers in the area of sustainable urban development and restitution of urban agriculture.

Montreal (Canada) is regarded among North American cities as a leader among cities promoting urban agriculture. The tradition of cultivating community gardens, which was brought by immigrants from France, became a permanent fixture of urban landscape. It also impacted the life style and leisure time of the city's inhabitants. Projects implemented in various districts to engage citizens, institutions and local authorities in the works for the benefit of urban agriculture are currently regarded as a model solution. A significant factor in stimulating the activity of local administration is the bottom-up force, i.e. social pressure from inhabitants, increasingly numerous and strong urban movements promoting urban greenery, and other bottom-up urban gardening initiatives. We can also see better and better organised citizens' initiatives that seek the interest and support of municipal authorities by various ways. An example is civil action initiative which, through public consultation on urban agriculture, led to the establishment of the Standing Committee of Urban Agriculture at the urban level. Apart from that, the authorities of the Metropolitan Community of Montreal $\left(\mathrm{CMM}^{3}\right)$ implement the provisions of the binding Metropolitan Management and Development Plan $\left(\mathrm{PMAD}^{4}\right)$, and inform the inhabitants about the progress of the implementation of Agricultural Zone Development Plans $\left(\mathrm{PDZA}^{5}\right)$ or projects designed to protect the greenery and water of Greater Montreal (Rapport..., 2015). Bhatt and Farah (2016) claim that organised actions, citizens' projects, bringing together of community groups and institutions, as well as formal cooperation with local authorities may play a crucial role in promoting urban agriculture. It should be added that Canada, as one of few countries, developed a National Strategy for

\footnotetext{
${ }^{2}$ Association of European Schools of Planning - AESOP.

${ }^{3}$ Communauté Métropolitaine de Montréal - CMM.

${ }^{4}$ Le Plan métropolitain d'aménagement et de développement - PMAD.

${ }^{5}$ Plans de développement de la zone agricole - PDZA.
} 
Urban Agriculture, which is in force in that country (Canada..., 2016). In France, the general aim of the document of urban strategic development, i.e. the so-called Directional Scheme of Management and Urban Planning (SDAU $\left.{ }^{6}, 1992-1995\right)$ was to maintain the essential balance between built-up areas (including those designed for development) on the one hand and natural, agricultural and forest areas on the other hand. The role of this document was already defined in the French Urban Planning Code dating back to 1987, which stated that "Directional Schemes establish the main directions of land use (...) taking into account the balance to be kept between urban development, agricultural activity, other economic activity and protection of natural areas" (Lyon 2010, 1991). The SDAU promotes compact development, strengthening of the polycentric layout, valorisation of public spaces in district centres, inhibition of urban sprawl in peri-urban municipalities as well as protection of environmental infrastructure, including urban and peri-urban agriculture. Moreover, the need to specify the concept of a food system was recognised, which, following Pillon (2011), was defined as a system of interdependent elements, i.e. entities, services and institutions responsible for food production, processing, distribution, access, consumption and storage. This comprehensive definition of a food system also included waste management and production of materials for agriculture (seeds, fertilizes, pesticides, among other things). The elements of this whole fulfil specific functions, and their interaction should be maintained in balance. It should be also noted that the actions of this system involve various types of resources: natural, economic, material, human and sociocultural, with external factors also being at play. French cities declare the desire to regain food autonomy. At a time of urban crisis they improve their food strategy in connection with the economic strategy (e.g. the city of Pousse), and implement public agricultural and food policy with territorial coverage at the supra-municipal level (Les villes..., 2015, 2017).

The European Metropolis of Lille (northern France) promotes itself as the first agricultural metropolis in France. It implemented a document called Food Autonomy, which defined land strategy as a new policy of Lille. Agriculture is maintained over the area of 35 ha within the metropolis, with particular support directed to its ecological, environment- and human friendly forms (Lille..., 2017). Similarly, the Metropolis of Montpellier (southern France) pursues, along with 31 associated municipalities, a new public policy, the so-called "agroecological and food" policy.

The French system of spatial planning, which is regarded as a model and addresses the issue of the restitution of agriculture and farmland, is successfully implemented in Lyon (France). An interesting example of the development of urban agricultural policy is the so-called "responsible agriculture" programme for the area of the Grand Parc Miribel Jonage park in the north-eastern part of Lyon, situated on a large island on the Rhone river (Grand..., 2020). The Strategy for Natural and Agricultural Areas developed for that area covers 2200 ha, including 800 ha of forests, 500 ha of agricultural areas, 56 ha of meadows covered by the

\footnotetext{
${ }^{6}$ Schéma Directeur d'Aménagement et d'Urbanisme - SDAU.
} 
Nature 2000 programme and 400 ha of water areas. The document set three directions for the Park's protection: to protect environmental diversity, valorise "responsible agriculture" and promote the area of environmental education and recreation as "territorial laboratory". The programme of agriculture in Grand Parc is an example of a new method of policy implementation that consists in improving the abilities to cooperate for achievement of objectives the sense of which is understandable to all.

Grand Parc had a medium-term Directional Plan with supporting documents (Agriculture Chart and Programme for Natural Area Management). The implementation of these documents enabled the initiation of dialogue with farmers, making them responsible partners in the protection of that area, as well as regulation of land use conditions. Before the deadline of the plan's implementation, i.e 2015, the already mentioned Strategy for Natural and Agricultural Areas was created which fits into the Agri-Environmental and Climate Project adopted for the whole territory. The project is designed to improve the professionalism of farmers and help in modification of their activity so that the quality of drinking water reserves and biodiversity could be preserved. The park is treated as a showcase for the metropolis, presenting the model environment and agriculture. This laboratory in the open air builds coherence of many themes by attracting new supporters of the project implementation. It is an area of cooperation between research institutions, universities and users (farmers, among others) and the aim is to take a more "sensitive approach" to the environmental protection through social dialogue. It is also an experiment of ambitious management, which is based on constant search for balance between the Park's various functions. This example of working together to implement a policy is at the same time an illustration of a new creative method for bringing into force plans and strategies.

Apart from the efforts of individual cities, the issues of "agroecological and food public policy" or territorially balanced food systems (a necessary component of the modern concept of sustainable urban development) are also addressed by France Urbaine - an association of maires and councillors of metropolises, agglomerations and large cities. The association set up a working group on "territorial food strategies" to help to develop and promote local projects and initiatives in that area also beyond France, as it initiates wider European reflection. Numerous French cities associated with France Urbaine became signatories of the Milan Urban Food Policy Act. At a European level, they intend to initiate a discussion on the place of cities and urban agriculture within the EU's Common Agricultural Policy and seek to establish urban agriculture regulations at the European scale. 


\section{Conclusion}

The concept of urban sustainable development still presents itself better in theory than in practice. There is a range of awareness, political and economic barriers that hinder actual efforts to implement this idea.

The first step in the evolution of the agricultural policy in the presented metropolitan areas was the mere recognition of urban and peri-urban agriculture as a problem directly connected with a city, and its inclusion in urban planning. The category of open areas, i.e. a perimeter of a green territory that included agricultural areas, was added to "project of metropolis". Thus, agriculture came under the sphere of responsibility of urban policy. All the documents of food strategies place a strong emphasis on preserving agricultural areas without their depletion.

Further redefinition of urban and peri-urban agriculture, along with food production, involved extending and strengthening its role in the aspect of an agglomeration's economic, ecological and social development. In agglomeration projects, agricultural activity was recognised as an economic sector in its own right. Moreover, the problem of the restitution of agriculture was extended to include food issues, i.e. the function of food supply to a city. Also, the importance of combining urban planning, agriculture and food for a city was stressed. Not only was agriculture recognised as a significant element of the landscape structure, but a new emphasis was placed on maintaining agricultural production activity.

The presented models of building urban food strategies show that only planning and a new generation strategic plan of a metropolis is able to balance long-term development objectives and protect natural resources for future generations. Agricultural areas are treated on a par with other forms of land use. Their significant importance due to their multifunctionality and landscape values is stressed. The Canadian or French solutions contribute to the maintenance and development of agriculture, constituting a model for many countries, including Central and Eastern European ones, where agricultural areas are still treated primarily as reserves for urban development.

\section{Acknowledgements}

The article is funded by National Science Centre, Poland under the project no 2016/21/D/HS4/00264. Prepared on the basis of a commissioned report entitled "The role of spatial planning in the restitution and development of urban agriculture ..." prepared by dr inż. arch. Ewa Heczko-Hyła. 


\section{References}

1. Ayambire, R.A., Amponsah, O., Peprah, C., Takyi, S.A. (2019). A review of practices for sustaining urban and peri-urban agriculture: Implications for land use planning in rapidly urbanising Ghanaian cities. Land Use Policy, 84, pp. 260-277.

2. Azunre, G.A., Amponsah, O., Peprah, C., Takyi, S.A., Braimah, I. (2019). A review of the role of urban agriculture in the sustainable city discourse. Cities, 93, pp. 104-119.

3. Bhatt, V., Farah, L.M. (2016). Cultivating Montreal: A Brief History of Citizens and Institutions. Integrating Urban Agriculture in the City. Urban agriculture and regional food systems. Available online: https://acsess.onlinelibrary.wiley.com/doi/10.2134/urbanag 2015.01.1511, 09.12.2020.

4. Canada: A National Strategy For Urban Agriculture (2016). Available online: http://cityfarmer.info/canada-a-national-strategy-for-urban-agriculture/, 09.12.2020.

5. Demailly, K.È., Darly, S. (2017). Urban agriculture on the move in Paris: The routes of temporary gardening in the neoliberal city. International Journal for Critical Geographies, 16(2), pp. 332-361.

6. FAO (2019). Urban Agriculture: FAO's Role in Urban Agriculture. Available online: fao.org/urban-agriculture/en/, 10.09.2019.

7. Ferreira, A.J.D., Guilherme, R.I.M.M., Ferreira, C.S.S. (2018). Urban agriculture, a tool towards more resilient urban communities? Current Opinion in Environmental Science \& Health, 5, pp. 93-97.

8. Grand Parc 2030. Stratégie Espaces naturels et agricoles (2020). Available online: https://www.grand-parc.fr/grand-parc-2030/, 10.12.2020.

9. Les villes à la reconquête de leur autonomie alimentaire (2015). Available online: terresenvilles.org/wp...TEV_CH3.2_PolAlimTerrLyon_2015.pdf/, 06.08.2018.

10. Les villes à la reconquête de leur autonomie alimentaire (2017). Available online: https://acteursdeleconomie.latribune.fr > Stratégie > Agriculture, 20.10.2017.

11. Lille - La MEL première métropole agricole de France (2017). Available online: http://www.autonomiealimentaire2020.info/mel-premiere-metropole-agricole-de-france/, 17.11.2018.

12. Local Food Action Plan - City of Vancouver (2013). Available online: vancouver.ca/files/cov/Local-food-action-plan.pdf, 12.12.2020.

13. Lyon 2010 (1991). Un Projet d'agglomeration pour une metropole Europeenne. Les grandes lignes du Schéma Directeur de l'agglomeration lyonnaise, Janvier 1991, Agence d' Urbanisme de la Communaute Urbaine de Lyon, 32.

14. Mansfield, B., Mendes, W. (2012). Municipal Food Strategies and Integrated Approaches to Urban Agriculture: Exploring Three Cases from the Global North. International Planning Studies 18(1). Available online: https://www.researchgate.net/publication/ 
234120166_Municipal_Food_Strategies_and_Integrated_Approaches_to_Urban_Agricult ure_Exploring_Three_Cases_from_the_Global_North, 11.02.2018.

15. Pillon, A. (2011). Le systeme alimentaire: un levier de developpement durable pour les territoires sous influence urbaine. Analyse comparative de stratégies alimentaires métropolitaines et des dynamiques à l'oeuvre sur l'agglomération lyonnaise, Mastère spécialisé ACTERRA, cursus GREF. Promotion 2010.

16. Pothukuchi, K., Kaufman, L.J. (2000). The Food System: A Stranger to the Planning Field. Journal of the American Planning Association, 66(2), pp. 13-24.

17. Rapport de monitoring du Plan métropolitain d'aménagement et de développement (2015). Available online: http://cmm.qc.ca/champs-intervention/amenagement/plans/pmad/, 11.12.2020.

18. Sarker, A.H., Bornman, J.F., Marinova, D. (2019). A framework for integrating agriculture in urban sustainability in Australia. Urban Science, 3(2), p. 50.

19. Schéma directeur d'aménagement et d'urbanisme de la région d'île de France (1976). Available online: https://www.aurbse.org/bibliographie/schema-directeur-damenagementet-durbanisme-de-la-region-dile-de-france-juillet-1976/, 20.10.2020.

20. Schéma directeur d'aménagement et d'urbanisme de la région d'île de France (1994). Available online: https://94.citoyens.com/wp-content/blogs.dir/2/files/2019/03/Sdrif1994.pdf, 20.10.2020.

21. Spataru, A., Faggian, R., Docking, A. (2020). Principles of multifunctional agriculture for supporting agriculture in metropolitan peri-urban areas: The case of Greater Melbourne Australia. Journal of Rural Studies, 74, pp. 34-44.

22. Specht, K., Weith, T., Swoboda, K., Siebert, R. (2016). Socially acceptable urban agriculture businesses. Agronomy for Sustainable Development, 36(1), pp. 1-14.

23. Urban Agriculture Strategy - City of London (2018). Available online: https://www.london.ca/business/.../Urban-Ag-Strategy.aspx, 07.01.2021.

24. Vidal, R., Fleury, A. (2009). La place de l'agriculture dans la métropole verte, publié dans Available online: http://www.projetsdepaysage.fr/fr/la_place_de_1_agriculture_dans_la_ metropole_verte, 03.01.2021. 